\title{
From Greenland to green lakes: Cultural eutrophication and the loss of benthic pathways in lakes
}

\author{
Yvonne Vadeboncoeur ${ }^{1}$ and Erik Jeppesen
}

National Environmental Research Institute, Vejlsøvej 25, DK-8600, Silkeborg, Denmark

\section{Jake Vander Zanden}

University of Wisconsin, Madison, Center for Limnology, 680 N. Park Street, Madison, Wisconsin 53706

\section{Hans-Henrik Schierup}

University of Aarhus, Department of Plant Ecology, Nordlandsvej 68, DK-8240 Risskov, Denmark

\section{Kirsten Christoffersen}

University of Copenhagen, Helsingørsgade 51, DK-3400, Hillerød, Denmark

\section{David M. Lodge}

Department of Biological Sciences, University of Notre Dame, Notre Dame, Indiana 46556

\begin{abstract}
Benthic community responses to lake eutrophication are poorly understood relative to pelagic responses. We compared phytoplankton and periphyton productivity along a eutrophication gradient in Greenland, U.S., and Danish lakes. Phytoplankton productivity increased along the phosphorus gradient (total phosphorus [TP] $=2-430 \mathrm{mg}$ $\mathrm{m}^{-3}$ ), but whole-lake benthic algal productivity decreased, substantially depressing increases in primary productivity at the whole-lake scale. In shallow, oligotrophic Greenland lakes, periphyton was responsible for 80-98\% of primary production, whereas in Danish lakes with TP $>100 \mathrm{mg} \mathrm{m}^{-3}$, phytoplankton were responsible for nearly $100 \%$ of primary production. Benthic contributions ranged from 5 to $80 \%$ depending on morphometry and littoral habitat composition in lakes with intermediate phosphorus concentrations. Thus, eutrophication was characterized by a switch from benthic to pelagic dominance of primary productivity. Carbon stable isotope analysis showed that the redistribution of primary production entailed a similar shift from periphyton to phytoplankton in the diets of zoobenthos. Benthic and pelagic habitats were energetically linked through food web interactions, but eutrophication eroded the benthic primary production pathway.
\end{abstract}

Eutrophication is one of the most common water quality problems in lakes worldwide. Phosphorus storage in sediments and diffuse loading from agricultural lands necessitate long-term ecosystem management to offset persistent effects of eutrophication in human-dominated landscapes (Jeppesen et al. 1991; Carpenter et al. 1998). Within this context, the

${ }^{1}$ To whom correspondence should be addressed. Present address: Ecology, Evolution, and Organismal Biology, Iowa State University, 124 Science II, Ames, Iowa 50011 (yvadeb@iastate.edu).

\section{Acknowledgments}

We thank Tue Jacobsen for field assistance and Lone Liboriussen for providing data on epiphytes in Danish lakes. Thanks also to Jim Kitchell and Steve Carpenter for providing phytoplankton and nutrient data for the U.S. lakes and to Zackenberg Ecological Research Operations for facilitating work in Greenland. Y.V. was supported by an NSF/NATO fellowship in Denmark and a GRIL postdoctoral fellowship at McGill University. Funding from the David H. Smith Conservation Research Fellowship of the Nature Conservancy and the National Science Foundation supported research in the United States. Work on the Danish and Greenland lakes was funded by the Ministry of Agriculture, Fisheries, and Food, the North Atlantic Research Programme, the Global Climate Change Programme, and the Danish Natural Science Research Council (SWF:2052-01-0034). relationship between total phytoplankton chlorophyll and water column phosphorus concentrations is a cornerstone of lake ecosystem theory. However, the ability of competitive interactions between macrophytes and phytoplankton to shift shallow lakes from clear to turbid states demonstrates that primary producer functional groups other than phytoplankton also affect ecosystem structure (Scheffer et al. 1993). Furthermore, food web analyses with stable isotopes of carbon consistently demonstrate that a broad array of fish taxa, up to the level of top predators, are energetically dependent on littoral attached algae (periphyton) as well as phytoplankton (Hecky and Hesslein 1995; Bootsma et al. 1996; Yoshii 1999; Vander Zanden and Vadeboncoeur 2002). The widespread reliance of fishes on carbon fixed by benthic algae has led to speculation that either ecologists are consistently underestimating attached algal primary production or that periphyton production is transferred up food webs more efficiently than phytoplankton (Hecky and Hesslein 1995). More accurately, limnologists often fail to estimate benthic primary productivity altogether (Vadeboncoeur et al. 2002). Existing relationships between water column phosphorus and periphyton biomass measured as chlorophyll reveal a weak or nonexistent influence of total phosphorus (TP) on 
periphyton (Cattaneo 1987; Hansson 1992). However, relating chlorophyll to water column phosphorus is confounded by a tendency for cellular chlorophyll content to increase, but overall productivity to decrease, when light levels are low. Therefore, in this study, we measured periphyton productivity at the whole-lake scale to incorporate the covariance of light and eutrophication gradients. Our purpose was to explore how periphyton production varies over eutrophication gradients and how this variation affects the energetic base of littoral food webs.

It has long been recognized that benthic and pelagic primary producers have the potential to compete for light and nutrients (Sand-Jensen and Borum 1991). However, the perception that a phytoplankton gradient is equivalent to an ecosystem-level primary productivity gradient persists in the absence of any comprehensive analysis of periphyton responses to eutrophication in lakes. Experimental and comparative evidence has shown that (1) phytoplankton sequester water column nutrients more rapidly than periphyton because periphyton uptake is constrained by boundary layer kinetics (Riber and Wetzel 1987; Reuter and Axler 1992), (2) periphytic algae have access to sediment-associated nutrients and regulate availability of those nutrients to phytoplankton (Hansson 1990), and (3) phytoplankton attenuate light, limiting periphyton production (Hansson 1992). These competitive interactions set up the possibility for inverse relationships between these two primary producer functional groups across eutrophication gradients (Sand-Jensen and Borum 1991; Havens et al. 2001), and fertilization experiments demonstrate a compensatory decline in periphyton production in response to increased phytoplankton biomass (Vadeboncoeur et al. 2001). However, most measurements of whole-lake benthic and pelagic primary production date back to the International Biosphere Program of the 1960s and 1970s. Unfortunately, these studies used a wide variety of methods and lack the accompanying phosphorus data needed to compare phytoplankton and periphyton responses to nutrient enrichment (summarized in Westlake et al. [1980] and Vadeboncoeur and Steinman [2002]).

Direct measurements of whole-lake primary production provide a first indication of the relative importance of different primary producer functional to lake food webs. However, stable isotope food web analysis gives a direct, integrative measure of assimilation of different carbon sources by consumers. Although many grazing taxa have strong topdown effects on periphyton (Steinman 1996; Hillebrand and Kahlert 2001), the importance of attached algae as an energy resource for the littoral invertebrate assemblage as a whole is poorly resolved for lakes (Lamberti 1996). The depauperate invertebrate communities of lake profundal zones are necessarily dependent on settling phytoplankton (Jónasson 1972; Goedkoop and Johnson 1996). In contrast, diverse littoral zone invertebrate assemblages might rely on multiple energy resources, including phytoplankton, periphyton, macrophytes, and detritus (James et al. 2000). Given that excessive phytoplankton production can depress both periphyton and macrophytes (Hansson 1992; Scheffer et al. 1993; Jeppesen et al. 1999; Vadeboncoeur et al. 2001), it is not surprising that littoral zoobenthic biomass and production do not exhibit simple monotonic relationships with phytoplank- ton or phosphorus. Loss of macrophyte habitat, increased predation from fish, and hypoxia at the sediment-water interface are potential negative effects of eutrophication on littoral zoobenthos (Rasmussen and Kalff 1987; Jeppesen et al. 1999). Here, we postulate that declines in periphyton and macrophytes caused by eutrophication might also represent a change in food resources for macroinvertebrates. Macroinvertebrate consumers might respond to changes in the availability of primary producer functional groups associated with eutrophication in two ways. First, species that specialize on periphyton or macrophyte production pathways might disappear from the invertebrate assemblage. Alternatively, generalist foragers might simply modify their diets to reflect the relative availability of different primary producer functional groups.

Carbon stable isotope analysis of consumer taxa within a lake can detect changes in resource use because phytoplankton discriminate against ${ }^{13} \mathrm{C}$ more than benthic algae do, and consumers conserve these differences (Hecky and Hesslein 1995). Stable isotope analysis is a complex tool. Determining $\delta^{13} \mathrm{C}$ of primary producers by direct measurement can be misleading because of temporal variability in $\delta^{13} \mathrm{C}$ of phytoplankton and because periphyton assemblages that are well developed and easy to sample (e.g., cyanobacteria mats and metaphyton blooms) might be conspicuous because they are not being consumed (Vinebrooke et al. 2001). Using primary consumers $\delta^{13} \mathrm{C}$ signals avoids both of these problems, giving a time-integrated signal of the actual resources exploited (Cabana and Rasmussen 1996; Vander Zanden and Rasmussen 1999). A second problem arises in that there are substantial lake-to-lake differences in primary producer baseline $\delta^{13} \mathrm{C}$ because of differences in dissolved inorganic carbon (DIC) associated with watershed characteristics and lake trophic status (Schindler et al. 1997). We used the within-lake difference in $\delta^{13} \mathrm{C}$ between consumer functional feeding groups as a response variable in this study. This approach reduces the stable isotope information from each lake to a single value that represents the isotopic range between consumer functional groups (e.g., grazers and filter feeders).

We measured the contribution of benthic algae to midsummer, whole-lake primary productivity in 27 lakes in Greenland, Denmark, and the United States spanning a TP gradient of 2-430 $\mathrm{mg} \mathrm{m}^{-3}$. In selecting lakes, our goal was to cover a broad range of TP. We were interested in quantifying benthic primary production in the Danish and U.S. lakes because intensive studies of top-down control of pelagic food webs in these lakes consistently pointed to a critical but variable energetic link between fish and littoral food webs (Schindler et al. 1996; Carpenter et al. 2001; Jeppesen et al. in press). We included the Greenland lakes in order to have pristine lakes with extremely low phytoplankton production and completely illuminated lake bottoms. Unfortunately, incorporating such a broad phosphorus gradient necessarily entailed including a confounding geographic gradient. We evaluated the dependence of zoobenthos on phytoplankton and periphyton across a narrower eutrophication gradient in 26 Danish lakes using stable isotopes of carbon to assess the importance of benthic algae to benthic invertebrates. Our results show that eutrophication caused a shift from dominance of benthic to pelagic algae and that this shift in dom- 
inance was transferred up the food web to littoral primary consumers and littoral invertebrate predators.

\section{Methods}

Primary productivity-Our study lakes included 11 oligotrophic arctic Greenland lakes $\left(z_{\text {avg }}=0.2-1.4 \mathrm{~m}\right), 4$ oligotrophic lakes in northeastern U.S. forests $\left(z_{\text {avg }}=3.7-5.7\right.$ $\mathrm{m})$, and 12 Danish lakes in forested, urban, and agricultural watersheds $\left(z_{\text {avg }}=0.8-10.5 \mathrm{~m}\right)$. Three of the U.S. lakes were experimentally fertilized for three consecutive summers, allowing us to directly measure the benthic algal response to eutrophication (Carpenter et al. 2001; Vadeboncoeur et al. $2001)$. Eighteen of the lakes are shallow with mean depths $<3 \mathrm{~m}$. We measured phytoplankton and attached algal primary productivity as a function of light intensity to a depth of $1 \%$ light in thermally stratified lakes and in the entire water column in shallow lakes. Midsummer phosphorus concentrations were derived from routine monitoring data for the U.S. (Carpenter et al. 2001) and Danish lakes (Jeppesen et al. 1999). Total phosphorus data from the Greenland lakes were single samples from the middle of the growing season and were analyzed following the methods for Danish lakes. We measured downwelling light attenuation with a Li-Cor LI-192SA Quantum underwater flat cosine sensor.

Both phytoplankton and periphyton productivity were measured with ${ }^{14} \mathrm{C}$. For phytoplankton, whole-water samples were collected from the epilimnion and incubated for $2 \mathrm{~h}$. Samples were then filtered onto membrane $(0.45 \mu \mathrm{m})$ filters, exposed to acid, dried, and counted on a scintillation counter. We measured periphyton primary productivity using intact communities on natural substrata following the methods published for the U.S. lakes (Vadeboncoeur et al. 2001). For algae on wood, rocks, and mosses, small pieces of the substratum were isolated in clear acrylic chambers and incubated with ${ }^{14} \mathrm{C}$ for $2 \mathrm{~h}$. Replicate light (two or three) and dark (one or two) chambers were incubated for each lake and substratum. We gently removed the periphyton from wood, mosses, and rocks with a soft brush and filtered a known proportion of the total sample. Filters were treated as described for phytoplankton. For epipelic algae, we used clear acrylic tubes (5.2 or $3.8 \mathrm{~cm}$ internal diameter) to collect intact sediment cores. Sediment cores were subjected to $2 \mathrm{~h}$ of darkness immediately prior to a 2-h light exposure to allow equilibration of ${ }^{14} \mathrm{C}$ between the interstitial and overlying water. After incubation, we sliced the top $1 \mathrm{~cm}$ of sediment from the core, freeze-dried it, exposed it to acid, and suspended a subsample in scintillation gel for scintillation counting. Dark uptake was subtracted from light uptake for both periphyton and phytoplankton. DIC was measured by gas chromatography or titrated with a $\mathrm{CO}_{2}$ Coulormeter (Model 5012, UIC, Inc.). Although similar ${ }^{14} \mathrm{C}$ productivity methods were used throughout, logistic and legal constraints determined sampling protocol for each group of lakes.

Greenland: Each Greenland lake was sampled once in the summer of 1999. In several of the lakes, it was impossible to sample the deep epipelic mats. Therefore, we have only included lakes $(n=7)$ for which we had periphyton measurements on all dominant benthic substrata for whole-lake periphyton estimates. However, data for phytoplankton, epiphyte, and epilithic production from all lakes are included in graphs of substratum-specific or habitat-specific estimates where appropriate. Phytoplankton was incubated at one to six depths depending on the shallowness of the lake. We collected small rocks, unconsolidated sediments, and mosses from the average depth and incubated them in situ. Hourly rates of epiphyte productivity per square meter of littoral zone was approximately 30 times that of moss (moss productivity was calculated based on annual biomass accrual Caning and Rasch (2000)). Therefore, competition between macrophytes and epiphytes for ${ }^{14} \mathrm{C}$ tracer should not have caused any detectable underestimates in epiphyte productivity. Relative surface area of substrata and macrophyte biomass were measured on two perpendicular transects across each lake. Depth was measured every $5 \mathrm{~m}$ to calculate average depth. The lakes were extremely clear and our light profiles indicated that periphyton photosynthesis was saturated at all depths on sunny days. In support of this assumption, incubation depth had no effect on phytoplankton productivity. Because the entire water column was illuminated, we calculated areal phytoplankton productivity by multiplying volumetric rates by average depth. For periphyton, we weighted productivity per square meter of each substratum by the relative proportion of the lake bottom area composed of that substratum. For moss substrata, we multiplied epiphyte productivity per gram moss by moss biomass per square meter. For epilithon, we assumed that onehalf of the surface area of the incubated rocks were colonized by periphyton and exposed to light. Bottom areas covered with large rocks had a greater surface area for periphyton colonization than areas of flat sediment because periphyton grew on vertical as well as horizontal rock surfaces (Loeb et al. 1983). The lake bottom covered with rocks was categorized based on rock size. From this, we derived conservative surface area correction factors based on the threedimensional structure of the different size groups. Small rocks $(<20 \mathrm{~cm}$ diameter) were treated as flat disks (dimension factor of 1), boulders $(>75 \mathrm{~cm}$ diameter) were treated as perfect spheres (dimension correction factor of 2), and the intermediate size group was given a dimension weighting factor of 1.5 .

Michigan: The four U.S. lakes are associated with the Trophic Cascade Project and have contrasting food web structures imposed through fish manipulations (Carpenter et al. 2001). Epipelic algae and phytoplankton were collected from multiple depths and wood was collected from $0.5 \mathrm{~m}$. Phytoplankton were incubated at multiple depths in situ within $3 \mathrm{~d}$ of the periphyton measurements (Carpenter et al. 2001). Periphyton samples were incubated in situ at the depth from which they were collected. Total surface area of wood was determined with a combination of direct measurement and quadrat sampling. Total benthic surface area and epilimnetic volume were determined for $0.1-\mathrm{m}$ strata depth using functions derived from bathymetric maps, and productivity in each layer was calculated using photosynthesis-irradiance relationships derived from the in situ incubations and lakespecific light attenuation coefficients $\left(K_{\mathrm{d}}\right)$. Light at depth $\left(I_{z}\right)$ 
was calculated using midsummer surface light intensities $\left(I_{0}\right)$ measured at a nearby weather station.

$$
I_{z}=I_{0} e^{-K_{\mathrm{d} z}}
$$

Total productivity on benthic surfaces and in the water column was summed over the photic zone and divided by total lake area to determine productivity per square meter (see Vadeboncoeur et al. 2001 for details)

Denmark: Twelve sediment cores were collected from the mean depth of the lake (unstratified lakes) or the epilimnion (stratified lakes). Cores were incubated under Philips SGR 200 metal halide lamps at multiple light intensities in the laboratory to generate photosynthesis-irradiance curves. We constructed photosynthesis-irradiance curves for both phytoplankton and sediments in the Danish lakes using the following equation (Kirk 1994).

$$
P=\frac{P_{\max } \alpha I}{\sqrt{\left(P_{\max }\right)^{2}+\alpha^{2} I^{2}}}
$$

Photoinhibition parameters were necessary in only four of the phytoplankton curves and none of the epipelic curves. Whole-lake benthic productivity was calculated using functions derived from bathymetric maps, photosynthesis-irradiance curves, and lake-specific light attenuation coefficients as described for the U.S. lakes. We used a midsummer incident radiation at the lake surface of $1,000 \mu \mathrm{mol} \mathrm{m}^{-2} \mathrm{~s}^{-1}$.

We underestimated productivity in some Danish lakes by not including epiphytes on fringing reed beds and macrophytes (epiphyte production was measured in the Greenland lakes, and macrophytes were rare in the U.S. lakes). For some of our study lakes, epiphyton production was measured on artificial substrata during the same summer as our study lakes (Liboriussen and Jeppesen 2003). This study showed that epiphyte production in the reed beds fringing the lakes accounted for $<1 \%$ of total (epipelon + epiphyte + phytoplankton) algal production. Four of the Danish lakes had $>5 \%$ submerged macrophyte cover $(9,20,80$, and $80 \%)$. Epiphyte production was measured on plastic strips in three of the four lakes (L. Liboriussen and E. Jeppesen unpubl. data), and we used the average of the three values for the fourth lake. We averaged maximum photosynthesis rates measured at $0.1,0.5$, and $0.9 \mathrm{~m}$ in the water column to determine potential productivity per square meter of macrophyte surface. Allen and Ocevski (1981) calculated that colonizable macrophyte surface area per square meter of littoral zone ranged from 0.15 to 1 for macrophyte assemblages in $2 \mathrm{~m}$ of water. We used a value of 1 , which assumes a monolayer of leaf surface area available for epiphyte colonization that is equal to the surface area of the lake bottom. Clearly, values $>1$ are possible but would result in high light attenuation as leaves shade each other. We multiplied areal rates on plastic strips by the percentage of lake surface colonized by macrophytes to estimate whole-lake epiphyte production.

The periphyton data are expressed three ways. We first present substratum-specific productivity rates averaged by geographic region to highlight the importance of substratum effects. Average productivity in the littoral zone depends on the distribution of both substrata and light. Therefore, at the next level of aggregation, we calculated phytoplankton and periphyton productivity per unit volume and surface area (respectively) of available habitat to a depth of $1 \%$ light availability. This is the appropriate level to examine the effects of water column phosphorus on average rates of photosynthesis for the two primary producer functional groups. Finally, we assessed total periphyton and phytoplankton primary production at the whole-lake scale by converting habitat-specific measurements to a per square meter of lake surface basis. This incorporates both the effects of nutrient gradients and the effects of lake morphometry on the relative contribution of the two functional groups to whole-lake primary productivity. We lacked sufficient statistical power to unequivocally separate the effects of region from TP concentrations. Therefore, simple linear regressions were performed with SYSTAT ${ }^{\circledR}$ (GLM), and each lake-year was treated as an independent observation.

Stable isotope analysis-In October 1998, we collected benthic invertebrates from 26 lakes in central and northern Jutland, Denmark. The lakes had phosphorus concentrations ranging from 11 to $790 \mathrm{mg} \mathrm{m}^{-3}$. We used sweep nets to collect from diverse habitats, including reed beds, macrophyte beds, and open sediments. Invertebrates were sorted and separated by taxa within $24 \mathrm{~h}$ and allowed to purge their guts for another $24 \mathrm{~h}$. The foot muscle of unionid mussels was sampled, and snails were removed from their shells. We used the whole body for all other organisms. Samples were dried at $60^{\circ} \mathrm{C}$ for $24 \mathrm{~h}$ and then ground in a mortar and pestle. We placed a $0.1-0.5-\mathrm{mg}$ sample in an aluminum foil capsule. Stable isotopes of $\mathrm{C}$ and $\mathrm{N}$ were analyzed on a FinneganMAT Delta Plus mass spectrophotometer at G.G. Hatch Isotope Laboratories, Ottawa, Ontario, Canada. $\delta^{13} \mathrm{C}$ is expressed on a per mil (\%o) basis relative to a Pee Dee Belemnite standard (Vander Zanden and Rasmussen 1999).

Our nonquantitative sampling methods did not allow us to examine species turnover of zoobenthos across the eutrophication gradient. Therefore, we focused on generalist taxa that were found in the majority of lakes and assessed their use of periphyton versus phytoplankton. Taxa were categorized into functional feeding groups based on feeding behavior. Unionid mussels are filter feeders that provide a reliable, time-integrated estimate of the phytoplankton $\delta^{13} \mathrm{C}$ signature (Cabana and Rasmussen 1996). We were unable to collect mussels from all lakes, so we averaged the signatures of mussels and the dipteran Chironomus plumosus to determine the phytoplankton $\delta^{13} \mathrm{C}$ signature. C. plumosus dominates the zoobenthos on the open sediments in Danish lakes and relies strongly on phytoplankton detritus (Jónasson 1972; Goedkoop and Johnson 1996; Hansen et al. 1998). However, it would be surprising if it did not feed opportunistically on epipelic algae in clear lakes. Based on data from the U.S. lakes, epipelic algae have a more positive signal than phytoplankton in oligotrophic lakes. Thus, our use of C. plumosus might cause us to overestimate the importance of phytoplankton by including epipelic consumption in the "phytoplankton" category in oligotrophic lakes. As such, using $C$. plumosus to determine phytoplankton endpoints 
constitutes a conservative bias of the importance of periphyton in lake food webs.

Amphipods and isopods occurred in the shallow fringing reed beds and have the potential to exploit detritus and algae on the sediments as well as epiphytes on reeds and macrophytes. Snails were often on the macrophytes and reed stems but are also likely to graze periphyton off sediments and rocks. We averaged the carbon signals of these three groups for a benthic grazer signal. The baseline $\delta^{13} \mathrm{C}$ of primary producers varies considerably among lakes, and primary consumers reflect this variability (Vander Zanden and Rasmussen 1999). We standardized among lakes by analyzing the difference between $\delta^{13} \mathrm{C}$ of filter feeders (mussels and chironomids) and the average $\delta^{13} \mathrm{C}$ signatures of taxa (amphipods, isopods, and snails) that collect material off macrophytes, reeds, sediments, and rocks. Diets of generalist predators provide an even more integrated view of the importance of primary producers to littoral food webs. Therefore, we averaged the signatures for common predators: leeches, damsel fly larvae (Coenagrionidae), megalopteran larvae (Sialidae), and coleopteran larvae (Dytiscidae). Again, we standardized each lake by calculating the difference between predator and filter feeder $\delta^{13} \mathrm{C}$. We regressed these differences on TP using SYSTAT ${ }^{\circledR}$ GLM procedure.

\section{Results}

Periphyton productivity was strongly influenced by substratum. In both Greenland and the United States, productivity per square meter of sediments was higher than area-specific rates on mosses, wood, or rocks (Fig. 1). The one exception was a thick $(1 \mathrm{~cm})$ mat covering the rocks in Lake Katherine in Greenland that had productivities similar to that on unconsolidated sediments in the U.S. lakes (Fig. 1). Across the entire trophic gradient, habitat-specific (per cubic meter epilimnion volume) phytoplankton production was positively correlated with epilimnion TP (Fig. 2a). Conversely, habitat-specific (per square meter littoral zone) periphyton productivity was negatively correlated with TP (Fig. 2b). Much of the variation in periphyton productivity is attributable to light availability. Regressing periphyton productivity on water column light attenuation $\left(K_{\mathrm{d}}\right)$ improved the fit $\left(\log _{10}\right.$ primary production $=-3.07 K_{\mathrm{d}}+1.7, R^{2}=0.54, p<$ $0.001)$ and made the TP effect nonsignificant $(p<0.6)$. Thus, the negative relationship between benthic algae and $\mathrm{TP}$ was primarily an indirect effect of phytoplankton intercepting downwelling light.

Given that the majority of the Danish study lakes had $<5 \%$ macrophyte cover, the fact that we did not measure epiphytes would have little detectable effect on most of our estimates of whole-lake productivity. For instance, in the lake with $9 \%$ macrophyte cover, estimated epiphyte productivity contributed $\sim 5 \%$ of littoral zone primary production (Fig. 2b). Conversely, in the two lakes with $80 \%$ macrophyte cover, epiphyte production probably contributed substantially to both littoral and whole-lake primary production (Figs. $2 \mathrm{~b}, \mathrm{~d}, 3)$. However, periphyton productivity per square meter littoral zone was a negative function of TP whether or not we included estimates of epiphyte production (Fig. 2b).

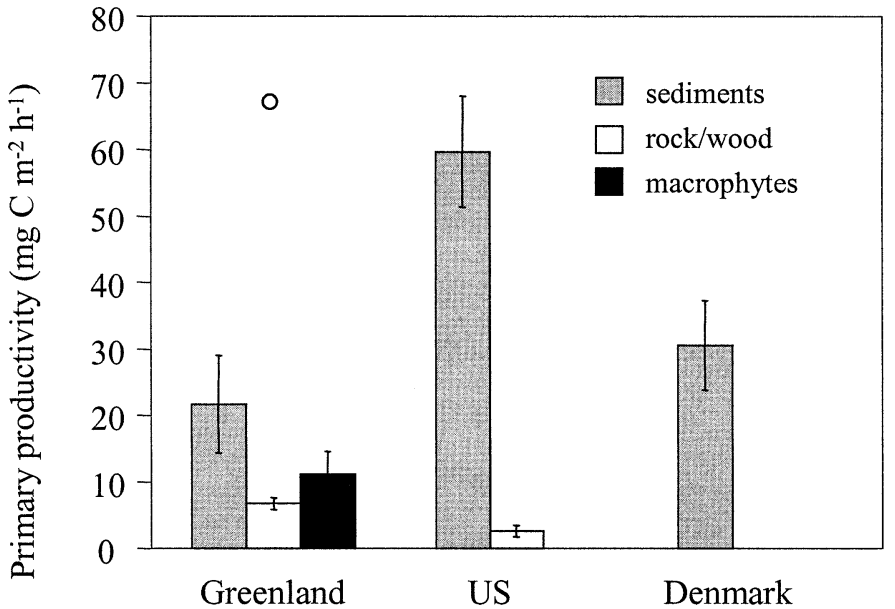

Fig. 1. Substratum-specific primary production by geographic region. In Greenland, substrata consisted of sediments with low organic content, rocks, and mosses. The point above the Greenland bar graph is the value of epilithic production for one of the study lakes that had an anomalous, 1-cm-thick, mat of algae covering the rocky bottom. In the U.S. lakes, sediments were highly organic, and the only other substratum was wood. In the Danish lakes, we measured only periphyton on sediments. Data for the Greenland and U.S. lakes are rates measured in situ at midday on sunny days and approach maximum photosynthesis rates (Vadeboncoeur and Lodge 2000). For the Danish Lakes, values are averages of maximum photosynthetic rates determined from photosynthesis-irradiance curves measured in the laboratory. Error bars are $1 \mathrm{SE}$.

In order to compare the distribution of total primary production among lakes, both phytoplankton and benthic algal primary productivity were expressed per square meter of lake surface area. Converting phytoplankton productivity from volumetric to areal units obscured the relationship with TP because total phytoplankton, but not total phosphorus, was summed over the water column (Fig. 2c). Nonetheless, the relationship between areal phytoplankton production and phosphorus remained positive and spanned almost four orders of magnitude. When both phytoplankton and periphyton were included in whole-lake primary production, the variation in primary production was much lower than for phytoplankton alone (Fig. 2c,d). The very oligotrophic Greenland lakes were dominated by periphyton productivity, whereas the very eutrophic Danish lakes were dominated by phytoplankton. At intermediate phosphorus concentrations, lakes showed a wide range in the percent contribution of periphyton (Fig. 3a). Our oligotrophic lakes in Greenland were small and shallow but the oligotrophic lakes in the United States and Denmark were deep and steep-sided. The interacting effects of phosphorus and lake morphometry are illustrated by summing TP over the depth of the epilimnion (i.e., just as phytoplankton productivity was summed to calculate areal rates). Integrating TP over the depth of the epilimnion reveals the inverse contributions of phytoplankton and periphyton to whole-lake primary productivity across gradients in lake depth and trophic status (Fig. 3b).

Stable carbon isotope signatures of grazing primary consumers (amphipods, isopods, and snails) and predators (leeches, odonates, megalopterans, and coleopterans) con- 

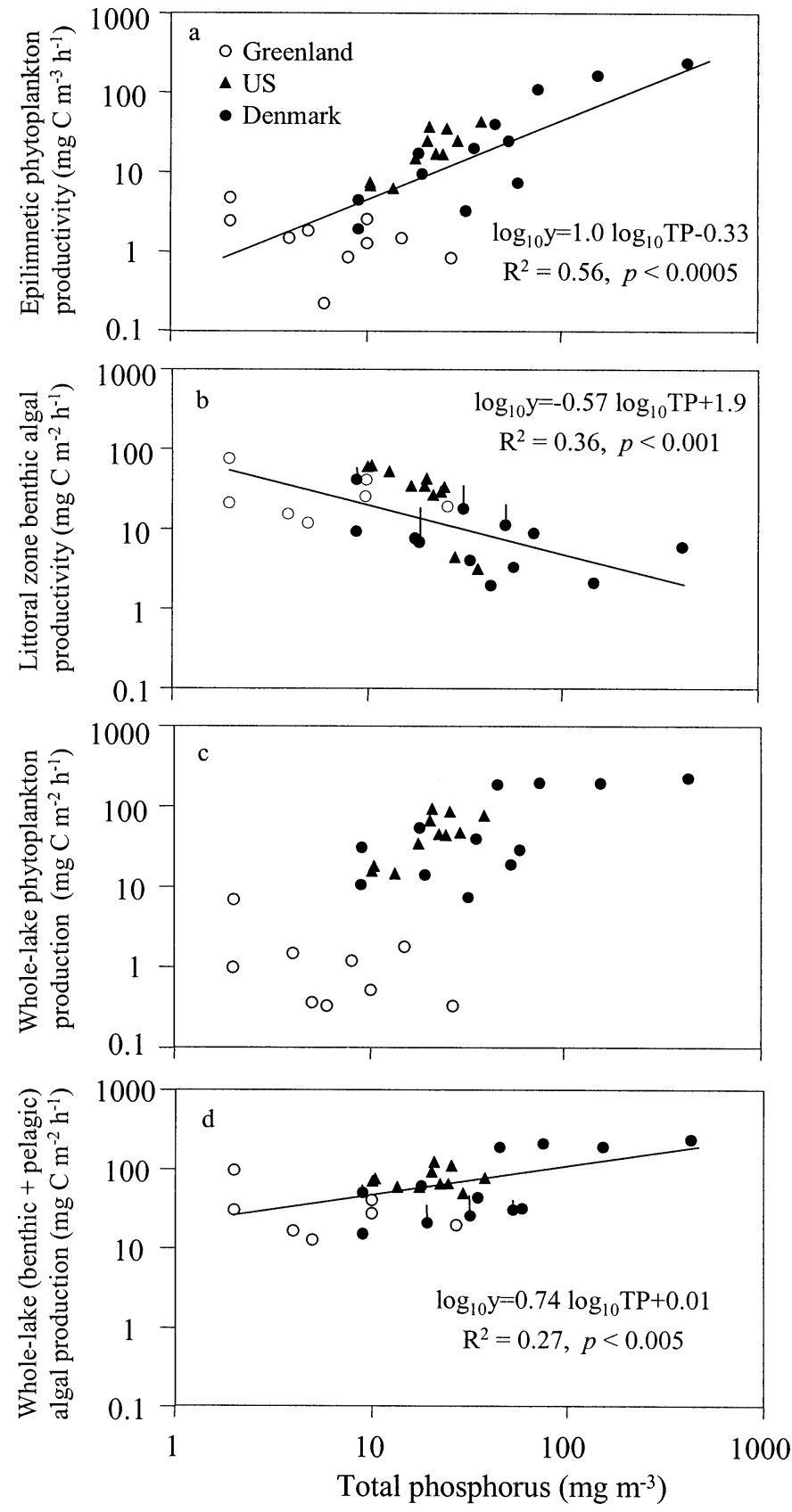

Fig. 2. Primary productivity as a function of epilimnion total phosphorus (TP). (a) Midsummer phytoplankton productivity in the epilimnion of lakes in Greenland, Denmark, and the United States. Each point represents a single lake-year. (b) Primary productivity of intact benthic algal communities per square meter of lake bottom in the epilimnion. (c) Phytoplankton productivity per square meter of lake surface area. (d) Whole-lake (benthic + pelagic) primary productivity per square meter of lake surface area. We used artificial substrata to estimate epiphytic contributions to primary productivity in four of the Danish lakes that had $>5 \%$ macrophyte cover (vertical lines extending from points, see text).

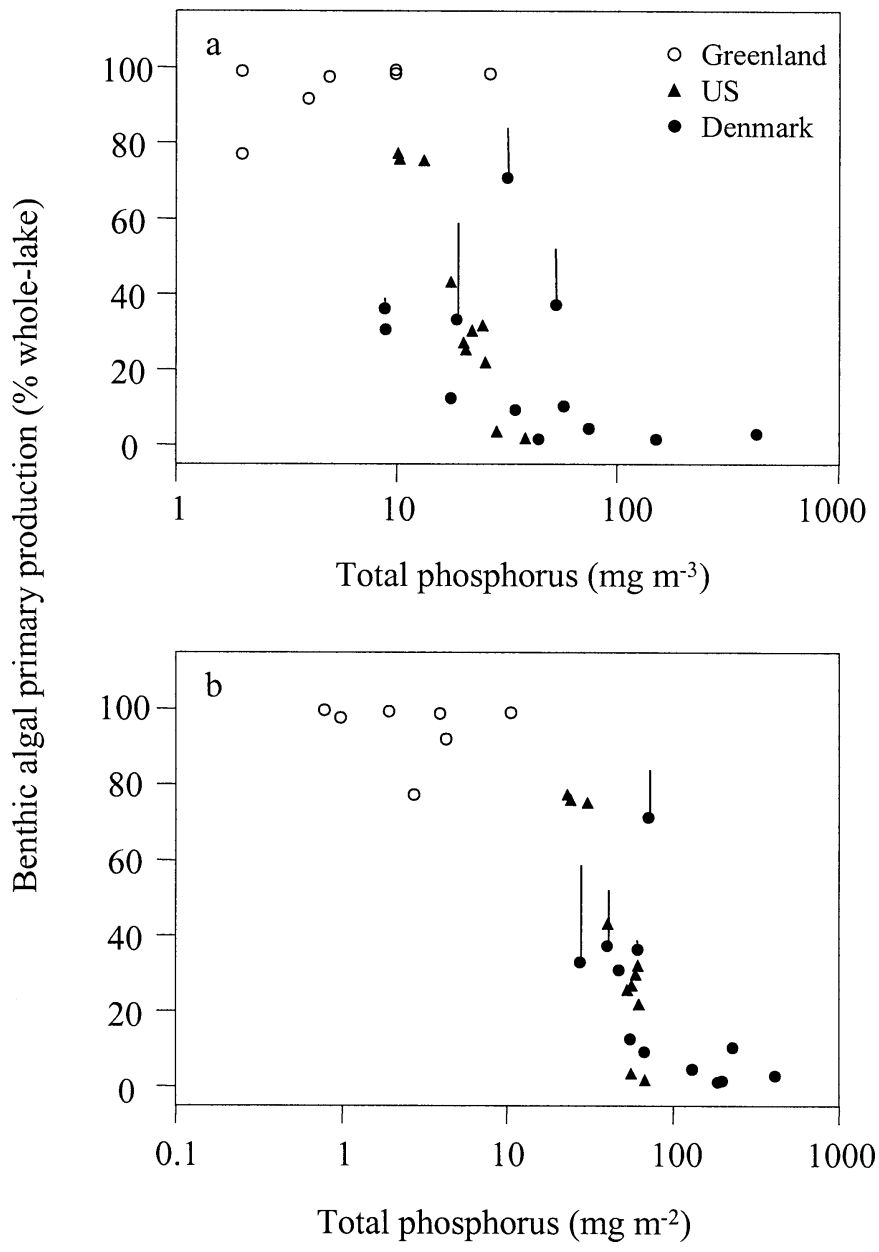

Fig. 3. (a) The relative contribution of benthic algae to wholelake primary production as a function of epilimnion TP concentration. (b) The contribution of benthic primary production is partly a function of the proportion of benthic versus pelagic habitat. To control for the confounding effects of deep versus shallow water columns on the total contribution of phytoplankton, we applied the same transformation to TP as we did for phytoplankton production; that is, we multiplied by mean depth of the mixed layer and expressed epilimnetic TP per square meter of lake surface. Vertical lines represent estimates of epiphyte productivity (see Fig. 2).

verged with those of filter feeders with increasing TP (Fig. $4 \mathrm{a}, \mathrm{b})$. In eutrophic lakes, $\delta^{13} \mathrm{C}$ of all littoral invertebrates tended toward $-26 \%$.

\section{Discussion}

Whole-lake benthic primary production has been reported for fewer than 30 lakes (Vadeboncoeur and Steinman 2002), and most of those studies predate both the development of phytoplankton-phosphorus relationships in lakes and the previous two decades of research on trophic cascades and biomanipulation. Similar to other aspects of littoral zone function, periphyton is poorly integrated into both conceptual and quantitative models of lake metabolism and food webs (Schindler and Scheurell 2002; Vadeboncoeur et al. 2002). Our results demonstrate that periphyton production 

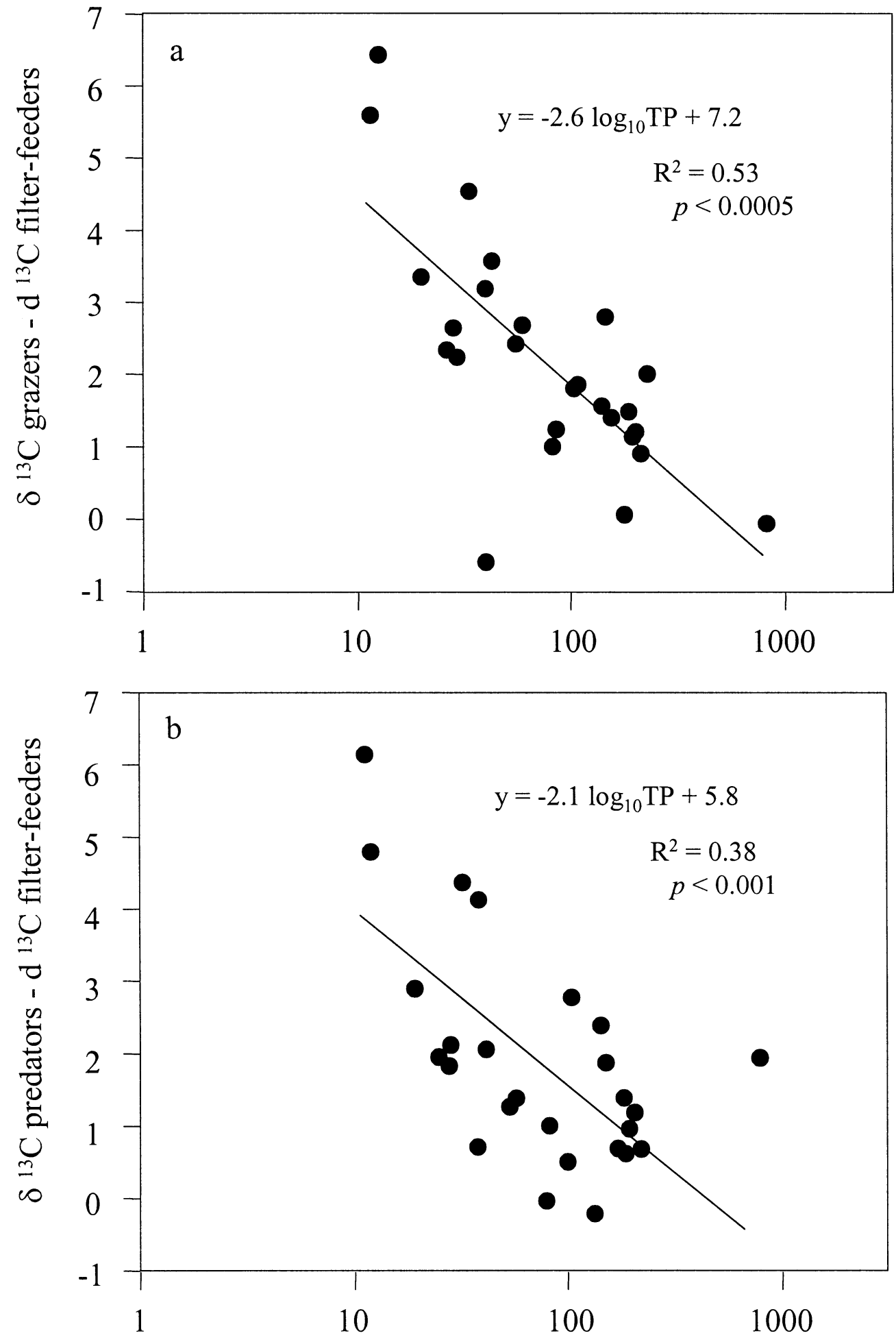

\section{Total phosphorus $\left(\mathrm{mg} \mathrm{m}^{-3}\right)$}

Fig. 4. (a) The difference in $\delta^{13} \mathrm{C}$ between zoobenthos that are pelagic feeders (mussels and Chironomus plumosus) and those that graze littoral surfaces (snails, isopods, amphipods) in Danish lakes. Each point is the difference between the mean $\delta^{13} \mathrm{C}$ of the two groups within a single lake. (b) The difference in $\delta^{13} \mathrm{C}$ between filter feeders and zoobenthic predators (leeches, odonates, megalopterans, and coleopterans). The large difference between the functional feeding groups at low TP suggests benthic algae and phytoplankton are both important energy sources. As TP increases, the convergence on $\delta^{13} \mathrm{C}$ $\approx-26 \%$ is consistent with phytoplankton or phytoplankton detritus being the main resource for zoobenthos in eutrophic lakes. 
was a substantial proportion of total lake primary productivity even in our steep-sided, deep study lakes in the United States. Interception of light by phytoplankton led to inverse relationships between periphyton and phytoplankton productivity and reduced variation in whole-lake primary production across the eutrophication gradient. Changes in the distribution of primary production were transferred up the food web and the carbon isotopic signatures of littoral invertebrates demonstrated increased exploitation of phytoplankton with increasing eutrophication.

The strong influence of substratum on periphyton productivity is similar to results from previous studies. Periphyton chlorophyll ( $\mathrm{mg} \mathrm{m}^{-2}$ substratum) on sediments was $2-100$ times that on substrata such as rocks, macrophytes, and wood in Canadian alpine lakes (Vinebrooke and Leavitt 1999), in an Ivory Coast reservoir (Thomas et al. 2000), and in streams in France (Maridet et al. 1998). In our U.S. study lakes, substratum-specific epipelic chlorophyll and productivity was 10 times that on wood; periphyton on wood, but not epipelon, responded positively to fertilization (Vadeboncoeur et al. 2001). The high productivity of epipelon relative to periphyton on other surfaces likely reflects different nutrient sources for the different assemblages. Periphyton uptake of water column nutrients is limited by boundary layer mass transfer and is low relative to phytoplankton (Riber and Wetzel 1987; Reuter and Axler 1992). However, periphyton on soft sediments have access to high concentrations of interstitial nutrients (Hansson 1992; Hillebrand and Kahlert 2001), whereas nutrient retention and recycling within the periphyton mat is an important nutrient source for periphyton on hard surfaces (Riber and Wetzel 1987; Axler and Reuter 1996).

Epipelic production dominated periphyton production in almost all of our study lakes. However, thick, persistent epilithic mats with productivity rates similar to those of epipelon often develop in large lakes where littoral zones are well lit below the depth of ice scour and severe wave action (Loeb et al. 1983; Hawes and Smith 1994b; O'Reilly 2001). The boulders in one of the Greenland lakes were covered by a 1-cm-thick felt of periphyton. This epilithic mat was 10 times as productive as periphyton on sandy sediments in the same lake (Fig. 1). Epiphytes sometimes dominate littoral zone primary production (McCormick et al. 1998), but our data indicate that epiphytes contributed substantially to total periphyton production only in the two Danish lakes with $80 \%$ macrophyte cover (Fig. 2b). As water column TP and phytoplankton biomass increase, the influence of substratumderived nutrients and nutrient recycling is offset by light limitation (Hansson 1992). In very eutrophic shallow lakes, the disturbance of sediments by wind and benthic-feeding fishes can exacerbate the effects of chronic exposure to low light, leading to the extremely low rates of epipelic production seen in some of our Danish study lakes.

It is extremely unlikely that the negative relationship between average littoral zone periphyton production and TP reflects a direct negative effect of TP on periphyton. Maximum phytoplankton photosynthetic rates, phytoplankton chlorophyll, and TP were all positively correlated with the light attenuation coefficient, $K_{\mathrm{d}}$. Thus, high phytoplankton chlorophyll associated with high TP reduces light penetra- tion. Increased light attenuation associated with increased phytoplankton biomass caused a reduction in both the total area of littoral habitat and the proportion of littoral habitat exposed to saturating light intensities. It is the latter process that drives the negative relationship between habitat-specific periphyton production and TP (Fig. 2b).

Because of the inverse relationships between phytoplankton and periphyton production (Fig. 2a,b), actual whole-lake primary productivity increased at a much lower rate than predicted by phytoplankton alone (Fig. 2d). Compilations of literature data have demonstrated that log-log regressions of phytoplankton chlorophyll on TP are sigmoidal rather than linear (McCauley et al. 1989). Phytoplankton biomass asymptotes in hypereutrophic lakes because, eventually, light will begin to limit even mixed-layer phytoplankton production (McCauley et al. 1989). Our results offer a new perspective on these findings: at the whole-ecosystem level, light limitation plays a role over most of the TP gradient, but it is initially imposed on periphyton assemblages and is only expressed in phytoplankton in extremely productive lakes (McCauley et al. 1989). In oligotrophic and mesotrophic lakes, increases in phytoplankton production with TP are partly offset by reductions in periphyton. Light attenuation by phytoplankton and self-shading by periphyton constrain integrated (benthic + pelagic) primary production (see Krause-Jensen and Sand-Jensen [1998] for a discussion of light limitation on integrated areal photosynthesis among different aquatic plant communities). The narrower range of whole-lake productivity relative to phytoplankton productivity (Fig. 2c,d) demonstrates that eutrophication was characterized not only by increased phytoplankton, but also by the redistribution of productivity from benthic to pelagic habitats (Fig. 3).

The intuitively attractive hypothesis that benthic primary production is only important in small or shallow lakes is confounded by interactions between morphometry and nutrient gradients (Lodge et al. 1998). Small and shallow lakes dominate the hydrologic landscape, and high ratios of littoral surface area relative to pelagic volume favor a strong influence of littoral and terrestrial processes (Wetzel 1990). However, small and shallow lakes are also highly susceptible to eutrophication, which inhibits light penetration to the benthos. In contrast, large deep lakes tend to be clear and support persistent, extremely productive periphyton mats (e.g., Lake Tahoe, U.S.A., Lake Taupo, New Zealand, Lake Tanganyika, Africa; Loeb et al. [1983]; Hawes and Smith [1994a]; O'Reilly [2001]). The mutual dependence of relative periphyton production on both depth and trophic status is illustrated in Fig. 3. In the shallow, clear Greenland lakes, $>80 \%$ of primary production was on benthic surfaces, whereas in highly eutrophic, shallow Danish lakes, productivity was almost exclusively pelagic. In mesotrophic and moderately deep lakes, the contribution of periphytic algae varied between 80 and 5\% (Fig. 3a). Our study lakes that were both low in TP and deep had a lower contribution of benthic productivity, as demonstrated by their tendency to shift right toward shallower lakes when we expressed TP on an areal basis (Fig. 3b). In deep lakes, the maximum contribution of benthic algae is constrained by morphometry, but deep lakes are also more resistant to catastrophic changes 
in light penetration (Scheffer 1998). Thus, we suggest that the range of the potential periphyton contribution, more so than its mean, is expected to be negatively correlated with average depth.

Our study encompassed a broad geographical range, leading to the possibility that other factors might either covary with the TP gradient or contribute to regional differences in the variation around the regression on TP. This is particularly true for the Greenland lakes, which were at a high latitude and had a short growing season and many of which lacked fish. Ultraviolet (UV) radiation, for instance, might negatively affect phytoplankton in the extremely clear Greenland lakes, but UV can enhance epipelic productivity (Vinebrooke and Leavitt 1999). Phytoplankton did not exhibit a positive relationship to TP in the Greenland lakes, potentially because of high zooplankton grazing in the fishless lakes (Mazumder 1994), but top-down effects do not cascade strongly to phytoplankton in these lakes (Jeppesen et al. in press). The more likely explanation is that the range of bioavailable $\mathrm{P}$ in the Greenland lakes was narrower than indicated by TP values. Both organic $\mathrm{P}$ and soluble reactive $\mathrm{P}$ were extremely low in the Greenland lakes. Thus, much of the TP was inorganic, but unavailable to the biota (E. Jeppesen unpubl. data).

Zoobenthic grazers contribute to variation in periphyton production (Steinman 1996; Hillebrand and Kahlert 2001). We did not monitor grazer densities in all lakes, but there is no indication that grazing contributed to the observed pattern of decreasing benthic primary production across the eutrophication gradient. Rather, densities of large benthic grazers were highest in the oligotrophic Greenland and U.S. lakes, which also had high periphyton productivity. In contrast, sediments of the eutrophic Danish lakes were dominated by chironomids. In fishless Greenland lakes, densities of the large zoobenthic omnivore Lepidurus acticus were as high as 245 individuals $\mathrm{m}^{-2}$ (Caning and Rasch 2000). When limnephilid caddisflies were experimentally excluded from plots in the U.S. lakes, primary production on sediments and wood increased by $50 \%$ (Vadeboncoeur and Lodge unpubl. data). Although this demonstrates strong top-down effects, at the same time, limnephilid caddisfly densities were highest (76 individuals $\mathrm{m}^{-2}$ ) in the U.S. lakes with the highest periphyton production. Thus, densities of large grazers appeared to be positively correlated with periphyton production (a bottom-up effect), but, at least in the U.S. lakes, grazers had a negative effect on periphyton (a top-down effect). These various observations indicate that grazers are likely an important source of variation in periphyton productivity, but their high densities did not negate the net positive effect of higher light availability in oligotrophic lakes.

Research on ecosystem-level consequences of inverse relationships between phytoplankton and benthic vascular plants has focused on the ability of macrophytes to physically inhibit sediment suspension and the role of macrophytes in providing structure that modifies predator-prey relationships among pelagic organisms (Scheffer 1998). Like macrophytes, benthic algae also affect nutrient and light availability by sequestering nutrients (Hansson 1990), by stabilizing sediments, and by reducing phosphorus mobility (Carlton and Wetzel 1988). In addition, benthic algae pro- vide a high turnover production base similar to phytoplankton that is an important resource in lake food webs (Hecky and Hesslein 1995). The loss of benthic algae with eutrophication could thus markedly alter energy flow through lake food webs.

The convergence of $\delta^{13} \mathrm{C}$ values that we observed with increased phosphorus concentrations (Fig. 4) indicates that either the diets of generalist consumers converged on a single primary production resource or the signals of primary producers themselves converged. In eutrophic lakes, the $\delta^{13} \mathrm{C}$ values of zoobenthos clustered around $-26 \%$, a value typical of both phytoplankton and terrestrial detritus. This cannot represent a convergence on macrophyte detritus because macrophytes have much more positive signals than phytoplankton (Hecky and Hesslein 1995; Yoshii 1999; James et al. 2000; Vadeboncoeur unpubl. data) and macrophytes did not occur in very eutrophic lakes (Jeppesen et al. 1999). Arguably, some of the variability in $\delta^{13} \mathrm{C}$ signals in oligotrophic lakes might be attributed to exploitation of macrophytes, but this only reinforces the conclusion that the convergence of consumer $\delta^{13} \mathrm{C}$ as a function of TP represents a shift away from littoral primary producers as an energy source for zoobenthos. Littoral food webs in eutrophic lakes became overwhelmingly fueled by either terrestrial detritus or, as is more likely given the extreme productivity of eutrophic Danish lakes, phytoplankton detritus. Although eutrophication can cause phytoplankton $\delta^{13} \mathrm{C}$ to become more positive from influx of atmospheric carbon (Schindler et al. 1997), eutrophication would cause concurrent increases in periphyton $\delta^{13} \mathrm{C}$ on any substrate that received adequate light. The most straightforward explanation of the convergence is that generalist primary consumer taxa switch to the same resource as filter-feeding taxa, phytoplankton. This is consistent with both the shift in primary production from benthic to pelagic habitats demonstrated by our primary production survey data and with the tendency for phytoplankton to settle out onto the sediments of eutrophic Danish lakes. The stable isotope data demonstrate that the energetic links between littoral and pelagic communities are fluid and strongly influenced by the relative production of primary producer functional groups. Change in resource use can occur by various mechanisms. For instance, the snail Bithynia tentaculata occurred in most of our study lakes. This snail grazes off surfaces but switches to filter feeding when phytoplankton concentrations are high (Brendelberger and Jürgens 1993). We monitored zoobenthos, but zooplankton also consume attached algae. Littoral predators such as odonates that exploit zooplankton (Burks et al. 2001) can thus change from periphyton primary production pathways to planktonic pathways because of resource switching by pelagic, rather than benthic, prey.

Our broad-scale survey indicates that primary production shifts from benthic to pelagic habitats with eutrophication and that gradients in whole-lake primary productivity are more gradual than exhibited by phytoplankton alone. However, much of the variability in these relationships remains to be related to littoral zone heterogeneity, benthic grazer density, and pelagic food web structure. The importance of periphyton-fixed carbon to fishes has been repeatedly demonstrated, especially in relatively unproductive lakes (Hecky 
and Hesslein 1995). Our stable isotope data fill an important gap, showing that a wide variety of littoral consumers depend on periphyton, but the littoral food base shifts to phytoplankton carbon as the periphyton food base is eroded. Benthic and pelagic food chains tend to be studied in isolation (Vadeboncoeur et al. 2002). However, interactions between primary producer functional groups and the consequences for zoobenthic consumers that we have illustrated here add to a growing number of studies, demonstrating that a multitude of habitat linkages profoundly affect lake and estuary ecosystem function (Palmer et al. 2000; Cloern 2001; Schindler and Scheurell 2002). Our data suggest that eutrophication varies the strength of two coexisting food chains that are linked at the bottom through primary producer competition for light and nutrients and at the top by fish foraging on zoobenthos. Other studies indicate that flexibility in foraging strategies of littoral and pelagic consumers affects nutrient transport between habitats (Schindler et al. 1996; Vanni 1996) and the ability of fish to exert top-down control on pelagic food chains (Schindler et al. 1996). A thorough exploration of how basin morphometry affects the strength of these linkages is lacking. However, food web studies from some of the world's deepest lakes, including Lake Baikal, Lake Tahoe, and Lake Malawi, demonstrate that a high proportion of the fish species in these lakes are dependent on littoral primary production (Hecky and Hesslein 1995; Bootsma et al. 1996; Yoshii 1999; Schindler and Scheurell 2002). The diminution of littoral resources described here might underlie changes in biodiversity and food web structure typically associated with eutrophication.

\section{References}

Allen, H. L., AND B. T. OCEvski. 1981. Comparative primary productivity of algal epiphytes on three species of macrophytes in the littoral of Lake Ohrid, Yugoslavia. Holarct. Ecol. 4: 155160.

AXler, R. P., AND J. E. REuter. 1996. Nitrate uptake by phytoplankton and periphyton: Whole-lake enrichments and mesocosm ${ }^{15} \mathrm{~N}$ experiments in an oligotrophic lake. Limnol. Oceanogr. 41: 659-671.

Bootsma, H. A., R. E. Hecky, R. H. Hesslein, and G. F. Turner. 1996. Food partitioning among lake Malawi nearshore fishes as revealed by stable isotope analysis. Ecology 77: 1286-1290.

BRENDELBERGER, H., AND S. JÜRGENS. 1993. Suspension feeding in Bithynia tentaculata (Prosobranchia, Bithyniidae) as affected by body size, food, and temperature. Oecologia 94: 36-42.

Burks, R. L., E. Jeppesen, AND D. M. Lodge. 2001. Pelagic prey and benthic predators: Impact of odonate predation on Daphnia. J. N. Am. Benthol. Soc. 20: 615-628.

Cabana, G., And J. B. Rasmussen. 1996. Comparison of aquatic food chains using nitrogen isotopes. Proc. Natl. Acad. Sci. USA 93: 10,844-10,847.

CANING, K., AND M. RASCH. 2000. Zackenberg ecological research operations, 5th annual report, 1999. Danish Polish Center, Ministry of Research and Information Technology.

Carlton, R. G., and R. G. Wetzel. 1988. Phosphorus flux from lake sediments: Effect of epipelic algal oxygen production. Limnol. Oceanogr. 33: 562-570.

Carpenter, S. R., N. F. Caraco, D. L. Correll, R. W. Howarth, A. N. Sharpley, And V. H. Smith. 1998. Nonpoint pollution of surface waters with phosphorus and nitrogen. Ecol. Appl. 8: $559-568$.
— AND OTHERS. 2001. Trophic cascades, nutrients, and lake productivity: Whole-lake experiments. Ecol. Monogr. 71: 163186.

Cattaneo, A. 1987. Periphyton in lakes of different trophy. Can. J. Fish. Aquat. Sci. 44: 296-303.

Cloern, J. E. 2001. Our evolving conceptual model of the coastal eutrophication problem. Mar. Ecol. Prog. Ser. 210: 223-253.

Goedkoop, W., AND R. K. Johnson. 1996. Pelagic-benthic coupling: Profundal benthic community response to spring diatom deposition in mesotrophic Lake Erken. Limnol. Oceanogr. 41: 636-647.

Hansen, K., S. Mouridsen, And E. Kristensen. 1998. The impact of Chironomus plumosus larvae on organic matter decay and nutrient $(\mathrm{N}, \mathrm{P})$ exchange in a shallow eutrophic lake sediment following a phytoplankton sedimentation. Hydrobiologia 364: $65-74$.

HANSSON, L.-A. 1990. Quantifying the impact of periphytic algae on nutrient availability for phytoplankton. Freshw. Biol. 24: 265-273.

- 1992. Factors regulating periphytic algal biomass. Limnol. Oceanogr. 37: 322-328.

HAVENS, K. E., AND OTHERS. 2001. Complex interactions between autotrophs in shallow marine and freshwater ecosystems: Implications for community responses to nutrient stress. Environ. Pollut. 113: 95-107.

Hawes, I., AND R. Smith. 1994a. Seasonal dynamics of epilithic periphtyon in oligotrophic Lake Taupo, New Zealand. N. Z. J. Mar. Freshw. Res. 28: 1-12.

$\longrightarrow$, AND 1 1994b. Seasonal dynamics of epilithic periphyton in oligotrophic Lake Taupo, New Zealand. N. Z. J. Mar. Freshw. Res. 28: 1-12.

Hecky, R. E., AND R. H. HessLeIn. 1995. Contributions of benthic algae to lake food webs as revealed by stable isotope analysis. J. N. Am. Benthol. Soc. 14: 631-653.

Hillebrand, H., AND M. KAHLERT. 2001. Effect of grazing and nutrient supply on periphyton biomass and nutrient stoichiometry in habitats of different productivity. Limnol. Oceanogr. 46: $1881-1898$.

James, M. A., I. Hawes, M. Weatherhead, C. Stanger, and M. GIBBS. 2000. Carbon flow in the littoral food web of an oligotrophic lake. Hydrobiologia 441: 93-106.

Jeppesen, E., P. Kristensen, J. P. Jensen, M. Søndergaard, E. MORTENSEN, AND T. LAURIDSEN. 1991. Recovery resilience following a reduction in external phosphorus loading of shallow eutrophic Danish lakes: Duration, regulating factors and methods for overcoming resilience. Mem. Ist. Ital. Idrobiol. 48: $137-148$

, J. P. Jensen, M. SøndergaArd, AND T. LAURidsen. 1999. Trophic dynamics in turbid and clearwater lakes with special emphasis on the role of zooplankton for water clarity. Hydrobiologia 408/409: 217-231.

- AND OTHERS. In press. The impact of nutrient state and lake depth on top-down control in the pelagic zone of lakes: Study of 466 lakes from the temperate zone to the arctic. Ecosystems.

JóNASSON, P. 1972. Ecology and production of the profundal benthos in relation to phytoplankton in Lake Esrom. Oikos (suppl.) 14: $1-148$.

KIRK, J. T. O. 1994. Light and photosynthesis in aquatic ecosystems, 2nd ed. Cambridge Univ. Press.

Krause-Jensen, D., And K. SAnd-Jensen. 1998. Light attenuation and photosynthesis of aquatic plant communities. Limnol. Oceanogr. 43: 396-407.

LAMBERTI, G. A. 1996. The role of periphyton in benthic food webs, p. 533-567. In R. J. Stevenson, M. L. Bothwell, and R. L. 
Lowe [eds.], Algal ecology: Freshwater benthic ecosystems. Aquatic ecology series. Academic Press.

Liboriussen, L., AND E. JePPESEN. 2003. Temporal dynamics in epipelic, pelagic and epiphytic algal production in a clear and a turbid shallow lake. Freshw. Biol. 48: 418-431.

Lodge, D. M., S. C. Blumenshine, AND Y. VAdeboncoeur. 1998. Insights and application of large-scale, long-term ecological observations and experiments, p. 202-237. In W. J. J. Resetarits and J. Bernardo [eds.], Experimental ecology: Issues and perspectives. Oxford Univ. Press.

Loeb, S. L., J. E. Reuter, AND C. R. Goldman. 1983. Littoral zone production of oligtrophic lakes, p. 161-167. In R. G. Wetzel [ed.], Periphyton of freshwater ecosystem. Dr. W. Junk.

Maridet, L., J.-G. Wasson, M. Philippe, C. Amoros, and R. J. NAIMAN. 1998. Trophic structure of three streams with contrasting riparian vegetation and geomorphology. Arch. Hydrobiol. 144: 61-85.

MAzumDer, A. 1994. Patterns of algal biomass in dominant oddvs. even-link lake ecosystems. Ecology 75: 1141-1149.

McCauley, E., J. A. Downing, And S. Watson. 1989. Sigmoid relationships between nutrients and chlorophyll among lakes. Can. J. Fish. Aquat. Sci. 46: 1171-1175.

McCormick, P. V., R. B. E. Shuford III, J. G. Backus, AND W. C. KENNEDY. 1998. Spatial and seasonal patterns of periphyton biomass and productivity in the northern Everglades, Florida, USA. Hydrobiologia 362: 185-208.

O'Reilly, C. M. 2001. The effects of land use change on littoral zone dynamics of Lake Tanganyika, East Africa. Department of Geosciences, Univ. of Arizona.

PAlmer, M. A., AND OTHERs. 2000. Linkages between aquatic sediment biota and life above sediments as potential drivers of biodiversity and ecological process. Bioscience 50: 10621075.

RASMUSSEN, J. B., AND J. KALFF. 1987. Empirical models for zoobenthic biomass in lakes. Can. J. Fish. Aquat. Sci. 44: 9901001.

Reuter, J. E., AND R. P. AXLER. 1992. Physiological characteristics of inorganic nitrogen uptake by spatially separate algal communities in a nitrogen-deficient lake. Freshw. Biol. 27: 227236.

Riber, H. H., AND R. G. Wetzel. 1987. Boundary-layer and internal diffusion effects on phosphorus fluxes in lake periphyton. Limnol. Oceanogr. 32: 1181-1194.

SAND-JENSEN, K., AND J. BorUM. 1991. Interactions among phytoplankton, periphyton, and macrophytes in temperate freshwaters and estuaries. Aquat. Bot. 41: 137-175.

SCHEFFER, M. 1998. The ecology of shallow lakes, 1st ed. Chapman and Hall.

- S. H. Hosper, M.-L. Meijer, B. Moss, and E. Jeppesen. 1993. Alternative equilibria in shallow lakes. Trends Ecol. Evol. 8: 275-279.

SCHINDLER, D. E., AND M. SCHEURELl. 2002. Habitat coupling in lake ecosystems. Oikos 98: 177-189.

- AND OTHERS. 1996. Food web structure and littoral zone coupling to pelagic trophic cascades, p. 96-105. In G. A. Polis and K. O. Winemiller [eds.], Food webs: Integration of patterns and dynamics. Chapman and Hall.

- S. R. CARPenter, J. J. Cole, J. F. Kitchell, And M. L. PACE. 1997. Influence of food web structure on carbon exchange between lakes and the atmosphere. Science 277: 248251.

Steinman, A. D. 1996. Effects of grazers on freshwater benthic algae, p. 341-373. In R. J. Stevenson, M. L. Bothwell, and R. L. Lowe [eds.], Algal ecology: Freshwater benthic ecosystems. Aquatic ecology series. Academic Press.

Thomas, S., P. Cecchi, D. Corbin, And J. Lemoalle. 2000. The different primary producers in a small African tropical reservoir during a drought: Temporal changes and interactions. Freshw. Biol. 45: 43-56.

Vadeboncoeur, Y., And A. D. Steinman. 2002. Periphyton function in lake ecosystems. Sci. World J. 2: 1449-1468.

—, AND D. M. LodGE. 2000. Periphyton production on wood and sediment: substratum-specific response to laboratory and whole-lake nutrient manipulations. J. N. Am. Benthol. Soc. 19: 68-81.

AND S. R. CARPENTER. 2001. Whole-lake fertilization effects on distribution of primary production between benthic and pelagic habitats. Ecology 82: 1065-1077.

- , M. J. Vander Zanden, And D. M. Lodge. 2002. Putting the lake back together: Reintegrating benthic pathways into lake food web models. BioScience 52: 44-55.

VAnder Zanden, M. J., AND J. B. Rasmussen. 1999. Primary consumer $\delta^{13} \mathrm{C}$ and $\delta^{15} \mathrm{~N}$ and the trophic position of aquatic consumers. Ecology 80: 1395-1404.

, AND Y. VADEBONCOEUR. 2002. Fishes as integrators of benthic and pelagic food webs in lakes. Ecology 83: 2152-2161.

VANNI, M. J. 1996. Nutrient transport and recycling by consumes in lake food webs: Implications for algal communities, p. 8195. In G. A. Polis and K. O. Winemiller [eds.], Food webs: Integration of pattern and dynamics. Chapman and Hall.

Vinebrooke, R. D., AND P. R. LeavitT. 1999. Phytobenthos and phytoplankton as potential indicators of climate change in mountain lakes and ponds: A HPLC-based pigment approach. J. N. Am. Benthol. Soc. 18: 15-33.

, M. A. Turner, K. A. Kidd, B. J. HANn, AND D. W. SChINDLER. 2001. Truncated food web effects of omnivorous minnows in a recovering acidified lake. J. N. Am. Benthol. Soc. 20: $629-642$.

Westlake, D. F., AND OTHERs. 1980. Primary production, p. 141246. In E. D. Le Cren and Lowe-McConnell [eds.], The functioning of freshwater ecosystems. International Biosphere Programme. Cambridge Univ. Press.

WetZEL, R. G. 1990. Land-water interfaces: Metabolic and limnological regulators. Int. Ver. für Theor. Angew. Limnol. 24: 6-24.

YoshII, K. 1999. Stable isotope analyses of benthic organisms in Lake Baikal. Hydrobiologia 411: 145-159.

Received: 22 October 2002

Accepted: 26 February 2003

Amended: 13 March 2003 